\title{
Current Problems of Autonomous Right of Vietnamese Universities and Its Management Measures
}

\author{
Anh Thu Vo \\ School of Humanities and Law \\ Northeastern University \\ Shenyang, China \\ Ho Chi Minh City University of Physical Education and \\ Sport \\ Ho Chi Minh, Vietnam
}

\author{
Wanbing Shi \\ School of Humanity and Law \\ Northeastern University \\ Shenyang, China
}

\begin{abstract}
Researching on autonomous right of Vietnamese universities contributes to raising its status and realizing its social service function. According to the current situation of autonomous right of Vietnamese universities, current problems related to it are revealed: the management system of Vietnamese universities and the rights and liabilities are ambiguous; autonomous right of Vietnamese universities hasn't been normalized; Vietnamese universities lack and need to establish board of directors. Management measures to realize autonomous right of Vietnamese universities are proposed: improve laws and regulations related to autonomous right of universities, and refer to foreign advanced experience to build safeguard and operation mechanism, in order to promote economic and social development in Vietnam.
\end{abstract}

Keywords-Vietnam; autonomous right of universities; problems; realization of autonomous right of universities; management measures

\section{INTRODUCTION}

At present, Vietnam enters the new development period after nearly thirty years of reform. Globalization creates conditions for Vietnam to build modern national undertakings, which are opportunities and challenges for social, economic and educational development, including the autonomous development of higher education in Vietnam. The construction of industrialized and modoern country requires tremendous human resources, but demand exceeds supply because of the weak capacity of Vietnamese education. Besides, the teaching reform of higher education in Vietnam develops slowly, neither keeping abreast of the development of market economy nor paying attention to demands of social development.

Higher education undertakes important tasks in economic globalization and the development of market economy. Autonomous development of higher education is the breakthrough of educational reform in Vietnam to guarantee

Fund project: Research result of national social science foundation pedagogy project "Research on Evaluation System of Scientific Research of Teachers in Humanities and Social Sciences of Universities" (Project No.: BFA150043). ten years of development of higher education in Vietnam.

In terms of themes of higher education, autonomous right doesn't mean exempting from legal saction and "freedom exists beyond legal provisions", but mean the integration of rights and liabilities. Autonomous rights of higher education refer to the right that autonomous subjects have full powers endowed by law, serve themsevles or organizations and number one through autonomous rights endowed by law, instead of being subordinate to others or other social organizations. Autonomous rights of higher education in Vietnam base on the relationships between Vietnamese government (Ministry of Education and Training) and universities. The government endows universities with selfmanagement. Vietnamese universities are legal entities that have rights to deal with internal affairs and run schools directly. In the end of the 20th century, Communist Party of Vietnam proposes in reform conference that autonomous rights of higher education should be step by step to carry out experimental and key implementation. According to the preliminary investigation, two biggest Vietnamese universities of "Vietnam National University, Hanoi and Vietnam National University, Ho Chi Minh City) have realized autonomous rights successfully.

\section{CURRENT SituATION AND PROBLEMS OF AUtONOMOUS RIGHTS OF VIETNAMESE UNIVERSITIES}

\section{A. Current Situation of Autonomous Right of Vietnamese Universities}

In the recent ten years, the autonomous rights of Vietnamese universities have positive transformation. Vietnamese government has introduced policies to vigorously accelerate autonomous rights of universities. Since 2003, Prime Minister of Vietnam Phan Van Khai has proposed "Vietnamese universities have autonomous rights in school planning, development planning, organization and training, scientific research, finance, international relationships, organization and personnel arrangement". [1] In 2005, Education Act in Vietnam emphasizes the important tasks of implementing 
higher education "Universities manage education and training independently". In 2009, the notice of joint session between Ministry of Education and Training and Department of the Interior proposes, "Implement autonomous rights of Vietnamese universities meanwhile promote universities to be responsible for internal management mechanism and personnel appointment". In 2012, Prime Minister of Vietnam Nguyen Tan Dung instructed on reform of autonomy of higher education that formulate "basic conditions and indexes of autonomous rights of Vietnamese universities" and check standards for enrollment scale and conditions of school operation of universities, laws and regulations to normalize independent scientific research, appointment, training plan, scientific research project and financial management. [2] A draft of Education Act is newly introduced in Vietnam which repeatedly proposes autonomous rights of Vietnamese universities in autonomy of school-running, self-management, independent recruitment, personnel employment and academic research system through rules and regulations of board of directors in universities.

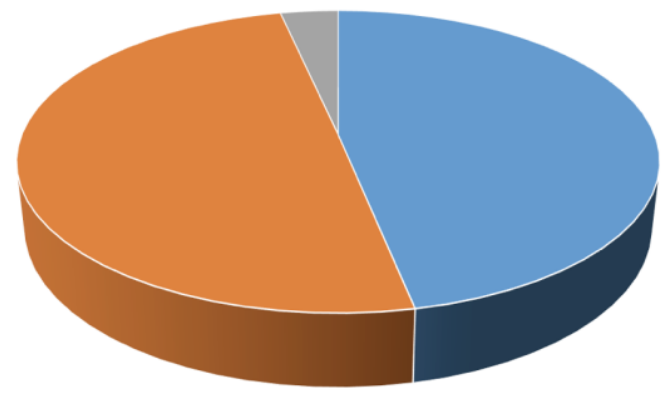
口
Universities

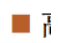
Junior
Autonomous rights of universities

Fig. 1. Situation of autonomous rights of Vietnamese universities in 2016

(Source: Ministry of Education and Training, report on data statistics of higher education from 2015 to 2016, official website: http://www.gso.gov.vn/)

At the beginning of 2016, according to the latest statistical report of Ministry of Education and Training, Vietnam have 436 institutions of higher learning, including 219 universities and 217 technical colleges. In the same year, Vietnamese government has conferred 15 universities the autonomous rights of national management. [3] The data statistics reveal only 3.4 percent of universities have autonomous rights in Vietnam, let alone the ten-year plan reform. Although Vietnamese government make efforts, in the globalization, practical results and real achievements of educational reform are required. It needs measures with realistic values for higher education instead of idle theorizing.

\section{B. Current Problems of Autonomous Rights of Vietnamese Universities}

1) Management system, rights and liabilities of Vietnamese universities are ambiguous.

Educational management is distinctly important for economic development of Vietnamese education. The management system of Vietnamese universities is ambiguous. Vietnam began to imitate the education system of the Soviet
Union in 1954 and kept it until 1975 when North and South Vietnam unified. Vietnam has adopted the management style of higher education for several decades. Although educational reform has realized, it brings little effect. Some measures are "slogan reform" superficially. In terms of national management, the Ministry of Education and Training is the largest responsible authority. Vietnamese provincial-level and local governments also can administrate universities. According to the data statistics in 2009, 54 national universities and 81 private universities are under direct administration of the Ministry of Education in Vietnam, accounting for 14.4 percent and 21.5 percent respectively. 116 universities are supervised by other units and 125 universities are supervised by provincial-level governments, accounting for 30.8 percent and 33.2 percent respectively. [4] Vietnamese law stipulates only the Ministry of Education and Training has rights to issue regulations of central level documents on Education and Management.

The regulations issued by the Ministry of Education are applicable to all Vietnamese universities. It is not the Ministry of Education but other administrative departments and provincial-level government sectors that supervise the implementation. Since Vietnamese universities are under the administration of Ministry of Education and Training and other provincial-level educational departments, it will lead to two problems. First, Vietnamese universities may receive the same guidance meanwhile. Second, provincial-level government sectors issue documents which have repeated contents even conflict with those issued by the Ministry of Education. "Documents with repeated contents" appear frequently. According to laws and regulations in Vietnam, the Ministry of Education and Training is the highest government agency for educational government and issues educational policies, and the implementation and supervision shall be carried out by other sectors or local governments. In this way, Vietnamese universities are restricted and administrated by many sectors in many aspects, which contradict with the autonomous rights of them.

Moreover, the inflexible management system suppresses educational development. Complicated procedures make it difficult to implement autonomous rights of Vietnamese universities. Vietnam government accredits the Ministry of Education to confer universities the enrollment autonomy and allocate practical capacities of universities. However, the propositions of Ministry of Education are unsound because the Vietnamese education system is decayed and inflexible. The ambiguous mechanism for application and approval severely influences the development vitality of universities. The mechanism of government review and approval is not improved. Besides, universities have got accustomed to depending on approval mechanism.

Some people think if Vietnamese government thoroughly administrates and restricts the operation of universities, it is difficult for the management of Vietnamese universities to produce effects. To some extent, the theoretical basis has effects. However, why Vietnam has so many universities of poor quality in the society with developed science and technology? It is because of the unsound educational management system. Besides, public and private universities 
are established at the meantime. Junior colleges are upgraded to universities. Therefore, the reduction of training quality of universities leads to unqualified graduates. In order to achieve the goal of ten-year plan for the development of education and training, Vietnamese government runs numerous universities and upgrades junior colleges to universities. The concrete measure is that in the first period up to 2010, among 10,000 Vietnamese, 200 people will be college students; in the second period up to 2020, among 10,000 Vietnamese, 450 people will be college students. [5] However, the general goal is unrealistic, leading to the reduction of education quality. To solve the problem, the National Assembly of Vietnam introduced "Decisions on the Establishment of New Universities and the Management of Its Training Quality" in 2010 at the same time established university supervisory commission.

Management system of Vietnamese universities is complicated and ambiguous. Ministry of Education and government sectors administrate universities at the same time. First, Vietnam National University, Hanoi exists in the north and Vietnam National University, Ho Chi Minh City exists in the south. Directly subordinate to the two universities, many universities are under the administration of the two universities and of the Ministry of Education and Training. Second, directly subordinate to local universities in Nam Ky, Bac Ky and Trung $\mathrm{Ky}$, some colleges are under the administration of local universities and of the Ministry of Education and Training. Third, universities are directly subordinate to local governments and are also administrated by the Ministry of Education and Training. The complicated layout of universities leads to chaotic university names, operation and management styles and measures. The system of education and training as well as the senior management in Vietnam are ambiguous.

A critical problem is that whether the autonomous rights of two central national universities in Vietnam are sufficient or "slogan". It is sensitive for universities directly subordinate to local governments and government sectors to apply for autonomous rights in senior management, organization and operation, finance, personnel employment, enrollment, training plan and scientific research. They only have autonomous rights partially.

Vietnamese universities adopt "stepped management style". Ministry of Education and Training is the highest administrative authority that directly manages the operation mode of universities. The problem is here. Affairs in universities even trifles are intervened and managed by the Ministry of Education according to the inflexble mechanism in the 1990s, influencing the development vitality of universities.

2) Autonomous rights of Vietnamese universities are not normalized.

In Vietnam, the autonomous rights of universities are not normalized and the concepts and connotations are not researched thoroughly. In order to optimize administration function of the government, the Ministry of Education and Training almost deals with all affairs in universities. The administrative accountability system of Administrative Law in Vietnam is unsound. Concepts like the list of government powers and the integration of rights and liabilities haven't appeared. All government sectors are at liberty in execution of power, which cannot stimulate the development vigor of education. Local public universities cannot decide for themselves without the authorization of government and must obey the written decision. The Ministry of Education and Training guides school affairs such as employment, appointment and removal of leaders, awarding posts of professor and associate professor, preparation of training plan, student enrollment, provision of new majors and tuition. The former director of the Education Department of the Ministry of Education and Training Chen Shixia addresses that the Ministry of Education and Training has conferred universities the autonomous rights, but they are limited to give full play to it. The questionnaire survey reveals universities must go through "application and approval" to open new disciplines and allocate enrollment index. [6]

Developed countries implement "the transformation from administration mechanism to supervision mechanism". The functions of Ministry of Education shall be drawing up education and training policies and formulating laws and regulations of education. Ministry of Education and Training in Vietnam should advance with the trend, formulate and supervise instead of participating in the process. Vietnamese universities should obtain autonomous rights that integrate rights and liabilities. Because "autonomous rights of Vietnamese universities" hasn't unified concept and executive standard and laws and regulations, universities have inconveniences in operation. The contradiction between operation mechanism and management style suppresses the development power of universities. To solve this problem, Ministry of Education in Vietnam should refer to the management systems of Chinese universities. In the construction of modern country, Chinese government pays attention to universities and regards it as an indispensable element in the development. Taking Tsinghua University and Peking University as example, Chinese government gives autonomous rights to them, which breathe new life into Chinese education and let the world look at them with new eyes. According to the rankings of universities in the world published on TIMES in the recent ten years, Tsinghua University and Peking University have been among the top 100 [7]

3) Vietnamese universities lack and should establish board of directors

In order to guarantee the autonomous rights and the integration of rights and liabilities, Vietnam universities are desperately in need of establishing board of directors. It proposes in Regulations on University Administration of Ministry of Education and Training in Vietnam in 2003 and 2010 that "promote universities to establish board of directors". Vietnamese universities have established board of directors but it is unsound.

Why Vietnamese universities need to establish "board of directors"? Departments in Vietnamese universities that have similar functions to board of directors in schools such as Student Work Department, Admission Department, Training Department, Academic Affairs Division and Logistics Service Department serve as consultants of principals and have no rights to supervise. The "principal" in universities make final decisions. Honorary representative of higher education science 
in Vietnam, professor Fan Fu addresses board of directors in universities includes government administration department, directors of departments, secretary of the party committee and labor union. Professor Fan regards the board of directors as administrative permanent body in universities. "Executive body" cannot completely take these departments as the highest administrative authorities in universities. [8] In principle, the supreme leaders of universities namely the principal make the final decision. Higher education in Vietnam has become the training that pursues generalization. The operation mechanism of market economy determines the educational development. Tuition instead of scientific research has become the priority among priorities. Therefore, traditional universities and scientific research are not valued and universities earn profits.

At present, administration management organizations and its leaders execute power. Universities become business-like and profit. Demand exceeds supply in higher education of Vietnam and the teaching quality drops. Although substantial students are willing to study as undergraduates, the supply of university education can only meet 25 percent of demands. The data statistics show the higher education in Vietnam fails to meet demands of the public to attend school. From the perspective of economics, monopoly will appear when demand exceeds supply. The current situation of higher education in Vietnam lets training in Vietnamese universities become monopolistic. Tuition and training expenses are ambiguous and non-transparent. Students only have one choice and no alternatives. Vietnamese government is strengthening autonomous rights of Vietnamese universities. The primary task is to realize "financial autonomy". Large public universities such as Hanoi National Economics University, University of Economics Ho Chi Minh City, and Hanoi University of Commerce become experimental units. Vietnamese universities transforms into the pattern of "sharing of rights and liabilities", from the top-down - top heavy pattern to the bottom-up - bottom heavy pattern, which means universities have rights to make decisions on education and training. It promotes the development of universities. Universities must take risks to make progress and make favorable decisions. Only the board of directors can shoulder the responsibility in making big decisions on important matters Nevertheless, the questionnaire results show almost all principals are unwilling to establish "board of directors". The most obvious reason is that the operation mechanism of board of directors repeats that of the party committee of the school.

Some people think according to the current situation of Vietnamese universities, the establishment of board of directors is an important issue. It will become "paint the lily" with blind operation, because principals cannot execute the orders of two sectors at the same time and place on the same affair. The opinion is right but not absolutely right. "Board of directors in Vietnamese universities" is creative factor for administration of Vietnamese universities and reform of higher education. It is beyond the ability of administrative management organizations and party committee of universities. Because the board of directors is independent and objective, the members of which are outside the school, it is distinctly important for the reform of autonomous rights and higher education in Vietnam. Meanwhile, proper establishment of board of directors will activate Vietnamese education and promotes the autonomous rights of Vietnamese universities, transforming from supervision by competent organizations to self-management. The measure implements No. 14 Decision of Vietnamese government in 2005 on cancellation of decision that government sectors administrate universities.

\section{Management Measures to Realize Autonomous RIGHTS OF VIETNAMESE UNIVERSITIES}

\section{A. Improve Laws and Regulations to Implement Autonomous Rights of Universities in Accordance with Law}

In order to realize autonomous rights with integration of rights and liabilities, school leaders should make full sense of autonomous rights and laws and regulations related to it. The establishment of autonomous rights cannot accomplish in an action but requires surefooted construction, conclusion of experience, comprehensive and objective evaluation.

\section{B. Refer to Foreign Advanced Experience to Improve Safeguard and Operation Mechanisms for Autonomous Rights of Universities}

The implementation of autonomous rights of universities should have uniform standard and key points. State administrative agencies should establish unified implementation mechanism, in which each member has autonomous rights, legal liabilities and administrative accountability liabilities. Reform of higher education in Vietnam should refer to advanced experience of autonomous rights in universities of the world. In order to realize autonomous rights of universities, Vietnamese government and Ministry of Education and Training should take the following steps:

First, scientists of higher education in and outside Vietnam should be invited to formulate higher education law in Vietnam.

Second, the higher education system of Vietnam consists of three layers: First, superior universities (about five key universities) are selected from fifteen national key universities and are mobilized to promote training and scientific research. At present, with restricted condition, some superior universities should be funded by the government to contribute to national development and make preparations for other universities. Second, reconstruct operation mechanism, teaching and research methods especially in universities with double tasks namely "universities with integration of teaching, research and development". The measure "kill two birds with one stone", trains high level talents and creates high quality products to make contributions for the development of market economy in Vietnam. Third, local universities should enhance vocational education and training and provide sufficient human resources, in order to promote the development of market economy. Meanwhile, inferior schools can be merged to establish vocational colleges to make joint efforts.

Third, superior universities are vested with autonomous rights and inferior colleges are administrated strictly. The suggestion is based on the opinions of Fan Yulun, the former minister of education in Vietnam proposed on the seminar of 
formulating draft of Vietnamese education act and management reform of universities in Hanoi on Apr. 20, 2011.

Fourth, universities should establish "board of directors with integration of accurate rights and liabilities" with offcampus personnel in the majority. Functions, rights and liabilities of board of directors, administrative departments and part committee in universities must be explicit. The execution of this measure transfers autonomous rights to board of directors in universities. The inflexible and restricted management of universities and higher education implemented by Vietnamese government sectors will be eliminated, to activate the self-innovation of higher education.

Fifth, reconstruct mechanisms with clear rights and responsibilities of two national universities and local colleges in Nam Ky, Bac Ky and Trung Ky to promote the development of universities.

\section{CONCLUSION}

The government has taken measures to improve the reform of university management and higher education. Since planned economic system has transformed into market economic system of socialism, Vietnamese universities should have autonomous rights to face challenges in globalization, in order to promote national development and meet demands of sustainable development and Vietnamese students. Autonomous right of universities is necessary and sufficient condition to reform management system and education. Vietnamese universities should take the lead to face challenges and share the responsibility of educational development. They fulfill tasks under the guidance of national government through self-evaluation and self-supervision, operate in accordance with the law, publicize operation procedures and integrate rights and liabilities. Responsible universities need the establishment of accountability mechanism. The realization of autonomous rights depends on governance ability. Accountability system of Vietnamese universities should be boosted to guarantee the interests of the country, people, social development and universities. Only transparent management system and autonomous rights of universities will be promising.

Autonomy and responsibility are inseparable and have theoretical dialectical relationship, namely the integration of rights and liabilities. Democracy and justice of a state are accompanied by rule of law and responsibility. Vietnamese government must implement autonomous rights and accountability system, so that the higher education will realize positive, active and creative development. The inflexible and restricted management system and education mechanism of "application and approval" are cancelled thoroughly.

Autonomous rights of Vietnamese universities should aim at training quality, reflecting on the employment of graduates. Projects learned and researched by students and vocational abilities of them must meet social demands. National development depends on occupation. National sustainable development is the responsibility of Vietnamese universities, higher education and management team in universities.

\section{REFERENCES}

[1] 2003 No. 153/2003/QĐ-TTg Written Decision of Prime Minister of Vietnam on Administration Regulations of Higher Education in Vietnam

[2] No. 296/CT-TTg Instructions of Prime Minister of Vietnam on Selection of Development Road for Higher Education in Vietnam on Feb.27, 2010

[3] http://dantri.com.vn/giao-duc-khuyen-hoc/vi-sao-cac-truong-dai-hocthuc-hien-tu-chu-nua-voi-20161026075345129.htm

[4] http://www.gso.gov.vn/default.aspx?tabid=722

[5] No. 14/2005/NQ-CP Resolution of Vietnamese Government on Comprehensively Promoting Reform of Higher Education in Vietnam from 2006 to 2010 on Nov.2, 2005

[6] http://vnexpress.net/tin-tuc/giao-duc/se-xoa-bo-co-quan-chu-quan-cuacac-dai-hoc-2156657.html

[7] https://www.timeshighereducation.com/world-universityrankings/2017/world-ranking

[8] https://voer.edu.vn/profile/69

[9] International Conference Publication of Professor Fan Fu, Honorary Representative of Higher Education Science in Vietnam, Autonomous Right and Board of Directors of Vietnamese Universities [J], Hanoi Educational Management College Press, 2006:11

[10] No. 07/2009/TTLT-BGDĐT-BNV Joint Notice of Ministry of Education and Department of the Interior of Vietnam, 2009:4

[11] Ministry of Education and Training, Regulations on Running of Universities, 2009

[12] Thomas J. Vallely và Ben Wilkinson, 2008. Vietnamese Higher Education: Crisis and Response, Memorandum Higher Education Task Force, Harvard Kenedy School, Ash Institute.

[13] Zhao Dayu, Li Tiejun, Chi Yanjie, Shi Wanbing, Tang Weimin. Theoretical Research and Comparative Research on Relationships between the Transformation of Government Functions and Autonomy of Universities in Running Schools, Liaoning Education Research, 2004, (11)

[14] Song Zhongying, Guo Yunyun. Connotation and Practice of Autonomy of Universities in Running Schools [J], Higher Education Exploration, 2016, (7)

[15] Anderson, D. \& Johnson, R., 1998, University Autonomy in Twenty Countries, Higher Education, Vol.98-3

[16] World bank, 2008, Vietnam:Higher Education and Skills for Growth, Human Development Department 